\title{
Questioning Morality and Religion in African Thought
}

\author{
Ephraim U. Ibekwe \\ Department of Philosophy, Imo State University, Owerri, Nigeria
}

How to cite this paper: Ibekwe, E. U. (2018). Questioning Morality and Religion in African Thought. The Educational Review, USA, 2(7), 397-409. http://dx.doi.org/10.26855/er.2018.07.005

Corresponding author: Ephraim U. Ibekwe, Department of Philosophy, Imo State University, Owerri, Nigeria.

\begin{abstract}
The article centers on current discourses on Morality and Religion in African thought. These discourses replicate the ambivalence between those scholars seeking to define African morality within the parameters of a conventionalized, Western, religious episteme, and those pursuing an "Africanist" (Afrocentric) explanation which embraces an authentic mode of African knowledge construction within indigenous communities. The assumption that faith or religion is the foundation of African morality does not hold water. However it can be partially endorsed when one grants space for hybrid moral constructions between Christianity and indigenous religion. This particular endeavour is problematic because of the complicated nature of African traditional religion System. However, there is a hope in this struggle for the redefinition of the constituents of African Morality issue as the concept "African morality" is not necessarily based on religion or faith, but on the beneficiary values of collective family and community well-being, without dissolving the individual's character. In African thought, the "best" rational justification of the moral imperative is less of an issue than in current moral discourse. This article points out distinctly that there is little or no demarcation between Morality and Religion in African thought as the two are closely related. It also argues for the continuity of African Religion.
\end{abstract}

\section{Keywords}

Africa, Morality and Religion

\section{Introduction}

Is there anything as morality in Africa? How actually does African Religion view the world and Humanity's place and role within it? What elements make up the Universe and how do they influence human life? What is the purpose of human existence, and what implications does this have for practical order of things? Given the affirmative answer to the first question, can there exist a some kind of hope for the common man in Africa? However, the answers to these questions that regularly appear in texts and debates "delineate the conception of morality in the universe, the understanding of the good that sustains life and the bad that destroys life." (Laurenti, 1997: 35). The hence, establish both the context and the content of African Morality, ethics and Religion.

It is evident from the title that this article attempts to clarify the concept of morality in African thought and to ascertain whether there is any intrinsic connection between it and religion. Apart from the confusion in scholarly debate regarding the exact meaning of the concepts "morality", "ethics", and "religion", there is also a more far-reaching inadequacy of the terminology used. In common scholarly discourse, knowledge is embraced in conceptual treatises by way of representational modes of 
knowledge, which implies that the concepts used represent knowledge of the world. Therefore, such concepts form the constituents of that knowledge. It may easily be assumed that the way in which all people know is similar and that they arrive at knowledge by means of correlating concepts or inferring in the same manner. However the question of knowing here is gullible because the faculties involved could be accused of been credulous. It is therefore important to investigate how people may know differently - how they acquire knowledge in terms of the way they know. The way in which indigenous people know what is morally right may not correlate with the way in which Western religious people know what is right. In the latter traditions, the individual is informed or instructed by being introduced to concepts that explain moral codes and expected ethical behaviour. The acquisition of this knowledge is based on cognition and most probably complemented by societal threats of repulsion or societal promises of reward. But this may not necessarily be the modes of acquisition of moral knowledge in indigenous societies with less emphasis on instruction in verbal (linguistic) modes. One should be aware that acquisition and construction of moral knowledge may be based on performance. The observation and experiencing of doing and performing may be the process for knowing what moral knowledge is. This knowledge is habituated and embedded in the action of community members and institutions of the group, and not necessarily taught.

Our inquiry, however difficult, should bear in mind that the way in which local, indigenous African communities know what is morally right, in other words their perception of morality, may be informed in ways different from societies in which moral and ethical codes are taught by means of instruction. Idangbo (2005), asserts that such instruction entails the appropriation of concepts in order to generate the way in which such societies think about morality, to clarify the way they know. One should further be aware of Mudimbe's criticism that the gnosis (the seeking to know and the systems of knowing) of the people of Africa should not be determined by the "non-African locus of Western epistemology" (Mudimbe, 1988).

Fraction of the basic building bricks of the Western episteme is the missionary's discourse, here categories of religious and Biblical thinking entered the logic of civilization, and henceforth promoted the idea that faith gives sense to ethics and not vice versa . Indigenous ethics was thus considered irrelevant if not discarded because of its non-faith propensity. There is an imminent danger in trying to portray morality in African thought in a homogeneous manner, thus continuing the colonial fixing of concepts of the indigenous. One is painfully aware of the shortcomings of one's endeavour to isolate a socio-cultural phenomenon of the African reality. The African post-colony is "a complex, multi-layered, and multivalent reality" (Kankuso, 2003: $34)$.

Paradoxically, any aspect of this reality is at nearly every historical moment both containment and a denial of its meaning or essence. What may seem to hold true for a specific country or context may be deconstructed in another encounter. The post-colony is not only hybrid in the sense of an irrational mix of colonial ideas and truly African expressions of belief and thought, but this hybridity, has become a productive space that critically challenges reigning ideas and generates meaning. One cannot, for example, only regard the fusion of borders between Christianity and indigenous religion as "syncretism", given the connotative meaning of this term. The hybrid interface between the two has rather become a productive and explorative space for the construction of new religious meaning, as may clearly be witnessed in the indigenous Apostolic Faith Churches. The ritual performances and spiritual retreat at the sacred sites of Badimong Valley (near Ficksburg) and Mothuleng (near Clarens) in the Eastern Free State exhibit hybrid forms of cultural and religious expressions which render the question of origin or influence almost pointless. The above is only a preliminary reflection of current views and is not based on empirical data. The concept "African thought" (instead of "African philosophy" to circumvent engagement with the diverse positions regarding a truly African philosophy) is in itself a complex concept which may suggest that there is a generic system of African thought. This would align with the idea of Asante that "there are generic features of the African reality" (cf Idah, 1995). However complex the issue is, it is possible to construe an Afrocentric approach, meaning a deliberate effort to seek authentic African expressions or views of reality. 


\section{The Concept of Morality}

Just as the concept of Religion is complex, so is morality. This is because there is no definite term of what could construe morality given the diverse nature of people's ideology, culture, values and tradition. However applying Kant's Universality in his categorical imperative, one may see that even though people's cultures differ, there could be cases of similarity and replication of moral principles. In sorting out what could count as morality in Africa, one should also bear in mind that the continent of Africa is made up of different people of different background, with different cultures and value, though with a definite correlation. However, it is this co-relatedness that may construe and define the African Morality. In terms of the Oxford Dictionary, morality refers to the moral principles pertaining to a distinction between right and wrong or good and evil. Morality is the sense and view of what is right and wrong and that which constitutes an absolute reference for character and behavior. It is an authoritative code of conduct in matters of right and wrong. It is usually seen in a broader sense than "ethics", although the margins are diffused. Even in this sense, however, varied traditions occur, for example the "Catholic" tradition of moral philosophy includes what other people would call ethics. "Ethics" refers to the acts of human behaviour informed by moral principles of good and evil (right and wrong).

However, ethical principles of conduct relate to absolute values that condition human behaviour, and in this sense it may correlate with moral assumptions of good and evil. If "ethos" denotes the categories and system of recommendable conduct, "ethos" and "morality" are interchangeable. In philosophical discourse, "ethics" is often included as a category of reflection "on the fundamental nature of morality and moral values" (Echewodo, 1988). It is therefore obvious that in parochial discourse, the interchangeable use will be noticeable when speaking of moral or ethical conduct. For the purposes of this article, "morality" refers to the moral system, and "ethics" to the actions relating to morals. Hence, reflection on African morality will concentrate on the absolute (normative) system informing the assumption and judgment of the nature and character of actions. Such a moral system may not necessarily be a philosophical or apprehensive system as text, but a system inductively construable from assumptions and actions of communities and individuals.

\section{The Concept of Religion}

To be precise, this article is not going to concern itself with definitions, theories and history of religion but would expose the concept of religion in Africa and the quest for its continuity. It is a well known fact that religion itself is complex in definition and analyses. It is a concept so cumbersome and complicated, such that one needs to exercise a lot of carefulness in trying to either define or analyze it. However, some scholars see its description as the best thing to do rather than embarking in the journey of definition or analyses. The aim is to avoid the error of inclusivism, exclusivism, particularism, or emotionalism. Howe ver, "many societies do not draw a clear line between their culture and what scholars would call "religion". This in essence does not mean that religion does not exist, but it is worth keeping in mind that even when we think we have a handle on what religion is, we might be fooling ourselves"' (Gbagbo, 2006; 56). Therefore, given the problematic nature of defining religion, there exists too some sorts of problems in saying what African religion is or is not. What African religion therefore is may not be clear to everyone; "the part to its understanding is often obscured by a conceptual overgrowth" (Festus, 2004).

There are many problems associated with the concept of Religion in Africa. Questions like whether African religion can properly be spoken of in the singular or only in the plural (African Religion or Religions). This question concerning the homogeneity or multiplicity of indigenous religious belief in Africa is of long lasting duration. Hence different scholars have applied different approaches to it. Western anthropologists/ethnologists and missionary scholars almost invariably considered the labels Africans attached to their religious phenomena as evidence of the non-existence of one basic, universal African religion. If there was just a thing approximating religion at all in Africa, the argued, it was "animism" "fetishism" or "Spiritism", a multiplicity of ritual actions with natural objects as deities. The logical implication of this notion at the time of this argument was for Christian mis- 
sionary to do everything possible to do away with the "the black man's spirits, give him a new sense of sins, do away with the practice of religion as a base on superstition and win him over to a new superior white God" (Van Der, 2003: 14). The criticism of the above view by African religion scholars like Mbiti is that African Religion is one in its essence. Although its varieties cannot be denied, but the varieties are much like those we encounter in any major religion, such as Christianity in form of denomination [Roman Catholic Church, Lutheran, Anglican, Presbyterian, or Baptist], or Islam (Shia, Suni, or Sufi). The remain Christian or Muslim Religion. To take African religion as African religions would doing so to Christianity and Muslim. Varieties in African religion must not be taken to mean diversity of fundamental belief. Thus, Jacques Manquet (1972:16) noted that "Africanity like every broad cultural synthesis,... is based on a similar experience of the world shared by various societies and on the dissemination of several cultural synthesis is based on a similar experience of the world shared by various societies" this is made possible by the development of similar ways of adapting to the natural environment and the diffusion of culture traits. These two mechanisms, each reinforcing the other, combine to create a common culture and a common religion.

Another contention is whether what we call African religion is simply a worldview like secularism and Humanism. However to take African Religion as equal to secularism would be erroneous as African religion is authentically built on issues supernatural , while concerning itself too with the well being of the society in maintaining the cultural and moral values, African religion is not simply an ideology.

The third questions for which we are concerned with is whether African Religion is a world Religion. There are certain objections to characterizing African Religion as a world religion. First, because African Religion has no written scriptures even some liberal Western Scholars of religion have been reluctant to consider it as any more than a tribal religion. World religions such as Judaism, Islam, Hinduism, or Christianity all have their own written sources. Western Scholars thus could neither conceive nor allow that a religion dependent on oral traditions such as African Religion is could be regarded as an equal. However, this argument cannot disqualify the universality of African Religion. These scholars failed to look carefully at history. The failed to consider that Judaism for example was an orally-based Religion for many centuries before its oral story was codified into writing. The same was true of Christianity and Islam. Ceteris paribus, orality alone cannot disqualify a religious system from qualitative greatness. In this sense, the existence of written scriptures must be seen as only one criterion among many.

These and many arguments continue against the backdrop that African Religion possesses a universal character per excellence. However, balanced and unprejudiced studies of African religion show that using even more significant criteria, it must be counted among the major world religions. The most important criterion is, of course, the understanding of the meaning of religion itself. Kung (1993: xvii) thus provides one of the most comprehensive descriptions of the term religion as a "a believing view of life, approach to life, way of life, and therefore a fundamental pattern embracing the individual and society, man and the world, through which a person sees and experiences, thinks and feels, acts and suffers, everything. It is transcendentally grounded and immanently operative system of coordinates by which man orients himself intellectual, emotionally, and existentially" Judging from the above an unbiased mind notices that African Religion fulfils all of these requirements, therefore can be called a world religion.

There has been a long lasting discussion on the importance of interreligious dialogue, the most occurring concept in those discussions is that the dialogue is the sole condition for peace and survival of our fractured and precarious universe. One strong advocate for this is Hans Kung. For him there can be no peace without religious Dialogue among world religious bodies. He emphasizes the need for scientific dialogue of religious specialists. According to Him, "We need a more intensive philosophical and theological dialogue of theologians and specialists in religion which takes religious plurality seriously in theological terms, accepts the challenge of the other religions and investigates their significance for each person's own religion" (Kung,1991: 137-8). However, seldom has there been the kind of dialogue in Africa that Kung and other strong voices envisage. Dialogue between Christianity and African Religion has never been in a real conversation at any of these levels. The irony of the whole 
issue is that contact between Christianity and African religion has historically been predominantly a monologue, bedeviled by assumptions, prejudiced against the latter, with Christianity culturally more vocal and ideologically more aggressive. There is the notion that indigenous African religion is the worship of idols, tress, seas, rivers, demigods and weather and that Africans who practice African traditional religions are going to hell, conversely, African religion has continue to serve as a moral voice to the people and society; harnessing the people's cultural values. Therefore, what we have heard until now is largely Christianity speaking about African religion not African religion speaking for itself. This has been the case in the area of moral or ethical thought, an important cornerstone of any religious system. Christian notions of Morality and ethics in academic studies have so overshadowed ethical notions of African religion that the latter have almost always come to be seen exclusively in the light of the former. The score card has been the intellectual suppression of the ethical points of view of African religion in academic circles and in many geographical areas of the continent where Christianity has succeeded in gaining large numbers of converts. Arguably is the fact that insofar as Africa and Africans themselves are concerned, this suppression has truly been minimal, more apparent than real and that despite the strong influence of Christianity in many areas of African life, the basic attitudes and religious philosophy of many Africans in fact perhaps more than in theory have been similar to that expressed many years ago by a Central African Kwena man to David Livingstones; "We should like you much better if you traded with us and then went away, without forever boring us with preaching that word of God yourself" (cf. Desai, 1962:2).

The west may accuse Africa and Africans of a lot of ills and attitudes, but it is laudable to note that moral perspectives of African Religion are essentially much alive throughout the continent. However, it is easy to be misled here, by using statistics on conversion to Christianity in his world Christian Encyclopedia, for example David Barret might give a mistaken impression that African religion is moving toward extinction in Africa. To show the persistent nature of African religion and its authenticity, Mbiti (1986:12) analyzes the situation and such statistics. For him acceptance of Christianity or any other religion in African means that Africans "Come out of African religion but they don't take off their traditional religiosity. They come as they are. They come as people whose world view is shaped according to African religion". Mbiti notes that there may be possibility of some changes during the exodus from African religion to any other, but puts forward the fact that they are "generally on the surface, affecting the material side of life, and only beginning to reach the deeper levels of thinking pattern, language content, mental images, emotions, beliefs and response in situations of need. Traditional concepts still form the essential background of many African peoples" (Mbiti, 1969).

\section{West and Textualization of African Religion}

The pre-colonial and colonial encounters with Africa have either discarded expressions of religion as barbarism and paganism or sought to relate recognizable expressions of religion to possible European religious influences. In general terms, the indigenous inhabitants are denied any form of authentic religious expression. It was a language of derision in terms of which pagan gods were ridiculed. According to Eboussi-Boulaga the "language of derision" was complemented with a "language of refutation" which entailed a systematic reduction of so-called pagan religion as the opposite of the good, i.e. evil or Satan. The languages of derision and refutation were further supplemented by a "language of demonstration" in terms of which the biblical religious categories were regarded as divine preference and command, thus forming part of the logic of civilization. In other words, the cultural model of the Bible was viewed as part of its message and, therefore, this was to replace so-called pagan cultural ideas and institutions. With the Christianization of the continent, the missionaries also started a Western textualization of African religion. Although they still continued a form of religious denial, the missionaries began to characterize indigen ous religious expressions in terms of the language and metaphors familiar to their religious categorization.

The authentic modes of indigenous conceptualization and indigenous modes of putting their religion into language were never the starting-point. For example, the aspects of healing in ritual practice were interpreted in terms of concepts of salvation, and 
concepts of sin were linked to what they regarded as reproachable conduct. Western religion thus provided the concepts as well as a frame of reference for interpreting the expression of African religion without an in-depth interrogation of the intertwined nature of aspects which the West regarded as religion, culture, and ritual. The physical and socio-cultural landscapes of the African person were altered to create the desired and convenient frame of religious analysis or interpretation. Twentieth-century textbooks on African religion still seek alignment with the categorical script of the Western science of religion. A critical examination of Mbiti's treatise of African religion reveals the frame of reference of the Western science of religion as well as an effort to "naturalize" indigenous religion to what is assumed to be the generic categorization of religion. However, Mudimbe and others consider these issues in a serious light. Mudimbe (1988) claims that the Western (missionary-influenced) systematization and familiarization of African indigenous religion do not take cognizance of (what he calls) the African gnosis: the way in which Africans view the world, their history, and how they know it. Serious interrogation of Western and Eurocentric religious discourses is required in order to place the African worldview in the centre.

Western religious discourse as well as continental religious voices require unmasking in order to arrive at a more authentic reflection on African religion. Leeuw (2004:20-36) goes further and states that "African religion is a misnomer, because the ideas behind actions of ritual and rite relate to African thought and not to religion-a concept not even accommodated originally in African languages". The problem addressed by Leeuw is not new, for in the majority of undifferentiated societies, on e would find it difficult to determine the boundaries between religion and thought. Depending on one's definition of religion, one may require, for the purpose of description, to list those aspects and expressions dealing with the ultimate meaning of life under the rubric of religion. This would not imply that there is no overlap between aspects of religion and culture; in fact there has never been an absolute distinction between the two, even in differentiated cultures.

There exists no normative African religion, only localized expressions and society-specific dimensions of sub-Sahara indigenous religion. It is indeed possible to determine generic aspects of this religion, but localized expressions differ. Ancestor belief has often been singled out as the most distinctive feature of African religion, and not without merit. However, the manner in which ancestor belief is concretized in a specific cultural or ethnic group differs. The approach of the ancestors in divination rituals differs, for example within the Sotho and Xhosa groups. In Sotho divination rituals, the ancestors are approached via prayer and ritual, and the diviner-healer will throw bones; in terms of the fall of bones, the ancestors' advice or instructions will be revealed. In the Xhosa tradition, ritual preparation to approach the ancestors is also required, but the ancestors do not "speak" through bones. In a much more intuitive manner, the body of the diviner-healer "senses" the message of the ancestors. The very notion of the ancestors also differs. The ancestors are generally not perceived to be ghosts or spirits, but living dead, and they are portrayed as departed family member(s) and thus identifiable family members. It is, however, also true that only specific members of the living dead, and not all deceased, occupy the position of ancestors. The traditions also differ regarding the patron ancestor responsible, for example, for the calling of becoming a diviner-healer. One should also consider the fact that, in an urbanized society, the concept of the ancestors is rapidly evolving into a more generalized concept, and that the specific tribal association is lost due to a dislocation from the patrilineal or matrilineal bonds.

Ancestor belief is, however, also integrated in what would generally be termed cultural practices, such as birth, name giving, marriage, etc. A system of belief does not exist distinctively from the cultural practices; it is a more holistic understanding of the dimensions of life. The spiritual is part and parcel of this holistic understanding of reality. Religion is culture and vice versa. Governing both is not a doctrine or universalistic script for practice, but a thought structure and performance repertoire typical of the continent. Although this thought structure may vary between groups and societies, recognizable universal traits are noticeable. One may call these universal patterns of thought an African indigenous cosmology.

The most common feature of this cosmology is the integration of three distinguishable aspects, namely environment, society, and the spiritual. All activities are informed by this holistic understanding so that they singularly or collectively maintain or 
transform the socio-cultural and spiritual landscape. An act is never separated from its environmental, societal, or spiritual impact. The cosmology becomes visible in that indigenous knowledge informs acts of technology, agriculture, animal keeping, music, song, dance, ritual, family care and parenting, tribal administration, the handling of conflict, etc. It is a system of thought embedded in action. One may even go so far as to state that this thought structure is embodied, because in many instances indigenous people react in immediate ways and in direct touch with their feelings. Intuitively they know how to act and what is required.

With the above reflection on the intricate relationship between culture, religion, and thought structure or cosmology, it should be obvious that the idea of an "African philosophy" may also cause confusion if philosophy is understood only in terms of the Western convention. I deliberately avoided the concept "philosophy" in the title for this reason. The debate concerning an authentic African philosophy has taken many turns (to mention but a few): from denying it (Hountondji 1983), to qualifying it as “primitive philosophy” (Levy-Bruhl 1963), Bantu Philosophy (Tempels 1969), consciencism (Nkruma), Negritude (Senghor 1996), Pan-Africanism (Nkru-mah) and sagacity or sage philosophy (Odera Oruka 1991) to deliberate efforts towards engaging with mainstream Western philosophy as self-critical reflection and a possible use of Hermeneutics in Theophilus Okere to categorize what could constitute an African Philosophy and Innocent Onyenwenyi's "Exercise in Afrocentricism" with the contention "that Africans have no philosophy and did not take any contribution to the study of philosophy which was transmitted to them by the Western Scholars as part of European education and civilization of Africa” (Onyenweenyi, 2015:283).

To a laudable extent, Mudimbe's position proves acceptable when he relates African philosophy to the authentic dimensions of African thought and cosmology. In other words, to escape the trap of classifying all myth, story, and sage wisdom as philos ophy, one should rather seek the authentic expressions of African philosophy in the African body of knowledge intrinsically related to what we may call "cosmology" and distinctive African modes of arriving at such knowledge. This knowledge is not a systematized collected body of knowledge expressed in text, but rather an informing system "behind" all action and reflection. The "body" of knowledge is never value-free nor does it end in its rational application. In fact, it relates to action and behaviour and has the wellness and healing of the individual and community at heart. The command of knowledge is not realized in seeking power and the promotion of its value in terms of its rationality, but in the value it adds to the well-being of people and communities.

\section{Morality in African Thought}

Mbiti's obvious Christian orientation is evident in his treatment of the perception of a creator god responsible for the establishment of a religious and moral order. African indigenous religion (if the generalization here may be excused) confirms the existence of a creator god, but it does not appear to be diffusing all aspects of religion in pregnant ways. A more apparent manifestation of African religion is the relatively meager representation of creation myths. Neither can it be confirmed that the indigenous African believes in a creator god by observing the universe, as Mbiti claims. Accordingly, it is also questionable whether the belief in a creator god dominates all other beliefs, as claimed by Mbiti.

Mbiti further claims that there exists a religious order of the universe and that the creator god is considered responsible for this. Similarly he claims that "God gave the moral order to people so that they might live happily and in harmony with one another". According to Mbiti, (1969) "one should view morality as an authoritative code of conduct directly sanctioned by god". The moral code is therefore not autonomous, but its autonomy is derived from the creator god. Any breach of the moral code would accordingly be an offence against god and his instruction. This view of Mbiti does not concur with his views regarding man's position at the centre of the universe, also reflected in creation myths. Mbiti does not relate the keeping of the moral code to any form of a concept regarding divine reward as one would expect from a divinely sanctioned code of conduct. When he elaborates on specific morals, the value is measured in terms of what governs individual and social acceptable conduct to the 
benefit of the well-being and to avoid taboos. When he further claims that these morals are embedded in people's practices, customs, and rituals and are transmitted through the generations, it appears that the morals are related to socially inscribed modes of actions derived from experiences of what is in the interest and well-being of the community. His assumption that God gives people their moral conduct and that he is the moral guardian is an unsubstantiated a priori. In this respect, Mbiti's exposition confirms Mudimbe's criticism of a "Christianization of the discourse about indigenous African religion" (cf. Uduala, 1996:34). It is obvious in this instance that Mbiti is still promoting the idea that faith in a creator god gives sense to morality and not the contrary. This controversy defines the two major critical positions regarding an African conceptualization of morality: One (e.g., Mbiti) claims that religion is the source and foundation of morality and the other promotes the idea that the moral imperative is logically independent from religion.

\section{African Religion's Conception of Morality}

There is the wide grown belief that African Religion's conception of morality is steep in tradition; it comes from and flows from God into the ancestors of the people. Here God is seen as the Great Ancestor, the prime founder and Progenitor, the Giver of life, the power behind everything that is. For Mbiti (1970:53-56), God is the first initiator of a people's way of life, its tradition. However, the ancestors the revered dead human progenitors of the clan or tribe, both remote and recent, are custodians of this tradition. They are its immediate reason for existence and they are ultimate purpose. The ancestors, who are in constant contact with both God and humanity often "intrude" into the life of humanity with specific intentions. They do so on their own or through the agency of the Spirits. The Spirits are active human beings who are either disincarnate human persons or powers residing in natural phenomenon such as trees, rocks, rivers, lakes, air or thunder. Like God and the ancestors, but of lesser power, the Spirits also play a part in the moral behavior of human beings. God, the ancestors and the Spirits are all powers or forces that impinge on human life in one way or another. In that way and sense they all are moral agents. The way they act has been determined by the ancestors and is stored in the tradition of the people-oral or written. Therefore, Tradition in Africa supplies the moral code and indicates what the people must do to live ethically and also the punishment for defaulters of certain code of conducts. The African moral code has its own particular emphases and orientation because the ancestors, from who it immediately derives and claims legitimation, had a certain self understanding, a view of their world and their place within it, a life style that was their own making and in which they felt at home, a religious attitude that responded to their experience of the transcendent in the immanent... a self-contained and independently developed cultural integrity that was sufficient for coping with the realities of their world experience (Mbefo 1993,73). This particular understanding of life-that which constitutes tradition is preserved and handed over from one generation to the next through Myth.

For Africans, yet for many other peoples of the world, Myth constitutes what scholars of language like Paul Ricoeur, have called "Primary language". It is a form of symbolic language that expresses the truths of human existence in a way that rational language cannot. But mythical language is not an irrational of expression as many suffice it to be. On the contrary Middleton (1967: x) notes that it “...is a statement about society and Man's place in it and in the surrounding universe. Such a statement is, in general, a symbolic one so that an important anthropological problem becomes one of understanding the reality that statement is used to symbolize". The irony here is that we face this same problem of interpretation with African myths, which contain elements with the greatest religious significance. Notwithstanding, myth contains a synopsis of the forces comprising the African moral conception of the Universe. The task however is to clarify the intricacies of the elements of tradition it contains, their interaction among themselves, and their relationship to human values and norms.

\section{Foundations of Moral Values and Norms}

In African Religion, the universe is a composite of divine, spirit, human, animate and inanimate elements, hierechichically 
perceived, but directly related, and always interacting with each other. Some of these elements are visible, while many others are invisible constituting the supernatural qualities of these elements. They correspond to the visible and invisible spheres of the universe; the visible world being composed of creation, including humanity, plants, animals and inanimate beings, and the invisible world being the sphere of God, the ancestors and the Spirits. These Placid Tempels reffered to as "vital forces (forces of life)" (Griaule and Dieterlen, 1954: 88). At the zenith of the hierarchy of the universe is the divine force, which is both the primary and the ultimate life giving power, God the creator and sustainer, the Holy. Geertz's understanding of ethics indicates that morality derives from people's understanding of the Holy. The holy does not only encourage commitment, Geertz points out, it demands it.

\section{Africa and Moral Consciousness}

It is worth doing here to address more explicitly the question of the general moral/ethical consciousness that the African view of the world engenders and enforces, for it is this consciousness that informs the whole of African moral life. Unequivocally, the African view or perception of the universe consists of the interaction of various vital forces, it follows then that the African ethical consciousness cannot but be a religious one. The world as a sacred abode of the life forces of God, the ancestors and diverse spirits is what gives human action its necessary sacred character. Consequently, African ethical consciousness must and does answer to religious demands.

Notably, African religion, including the world view it gives rise to and incorporates is entirely a lived religion, not a doctrinal one. It requires no formal induction. One is born into it and one learns it from Childhood throughout one's life through agents and agencies of socialization. It is a religion that is taken for granted within the community and generally needs neither proselytizers nor converts. Even people brought into a different ethnic group as for example, through capture, were not required to abandon their own spirits and ancestors. Instead, these were usually accepted as a cherished addition to the spirits and ancestors of the dominant group. Since it involves the whole life, whatever one thinks, says or does is religious or at least can have religious implications. At all times in a person's life, a religious consciousness is always explicitly or implicitly present. In no way is anything understood apart from context of God, the ancestor, and the spirits, in o way is any thought, word or act understood except in terms of good and bad, in the sense that such an attitude or behavior either enhances or diminishes life.

African religion thus forms the African people's ethical or moral consciousness as a whole united system wherein each factor influences the other. In this system "being" is the same as doing and vice versa. Thus, "not until one has understood that for the African [the ontologically good is the ethically good, can one appreciate and understand the moral sense of the African and the direction of ethical pursuit" (Adegbola, 1969: 118).

\section{Views of African Morality}

For the purposes of our explorative approach, the views of prominent scholars on African morality will be briefly examined, and an attempt will be made to conceptualize these with reference to moral autonomy. Setiloane, one of the pertinent voices on African religion in South Africa takes his cue from the genesis myth regarding "the origin of people from a hole in the ground, a widespread myth among southern and central African peoples" (Setiloane, 1998). In terms of the hole in the ground myth the first people came out of the ground together with their immediate kin and animals under the direction of Modimo (God). They were a community of people and animals, and did not appear as individuals. The animal and human world were one and were sustained by mother earth and exposed to the same natural elements. Modimo was the driving force in all phenomena of this world, including the inanimate. Accordingly, Setiloane (1998: 24) states that "the term community is inclusive of all life (bios): animals, the habitat (the land), flora, and even the elements. The success of life is found in the ability to maintain a healthy relationship with all”. 
The moral imperative and contract is to be in harmony with the community and to ensure its continuance. The cycle of ritual life is to restore this wholeness of the community of human beings, nature, and the elements. An act of violence is viewed as an act disturbing the equilibrium or balance of the community. An indecent act, which destroys community life and which is directed against the principle of Botho-Ubuntu, will not be left unpunished in this world; retribution is not retained for the hereafter only. The moral imperative is co-habitual in the sense that it is part of the entire concept of being part of a comprehensive community, divinely destined by Modimo. The moral code is not directly linked to the instruction of Modimo, but to the responsibility of maintaining the wellness of the community created by Modimo. In this sense, the morality is linked to the societal imperative as an essential element for self-preservation. It is obvious that Setiloane adjusts the absolute societal motivation slightly in terms of the view of Modimo as the fons et origo of the community. Other African scholars have taken this further in order to advance the notion that if God is the origin of the community and made man, he is the source of man's conscience, including his sense of right and wrong. This position may be understood to be a confirmation that religion is the source of morality. It is, however, more nuanced in the sense that the recognition of the deity does not easily translate into religion in its common understanding.

In Bantu Philosophy (1959) the ethno philosopher Placid Temples expresses the opinion that African cultural beliefs and practices exhibit an ontological or metaphysical principle, which is the invisible cause of life and death as well as of all actions. This "vital force" is a cardinal value in African thought upon which all things, animate and inanimate, are founded and which is the creative force behind all human and non-human action. It is an "interpenetrating and permeating" (Odeh, 1994: 25) power in the universe. The moral imperative relates to the presence of this vital force and has nothing to do with a fear related to so-called animism. Although the vital force may be associated with the divine in the universe, it is not experienced as divine intervention, and therefore the moral imperative is a direct outcome of this force without linking it to specific instruction of the deity. Thus one cannot state that religion precedes the concept of morality. Although morality is part of religious belief (or of ontology, as Tempels would say), the moral imperative is to achieve right relationships between the individual, the community, and the environment and is in a way "self-evidently right" (Hammand-Tooke 1998: 8). Accordingly, communities instinctively understand good and evil. The moral is almost a product of a common sense regard for the vital force. There should be no action against this vital force, and the moral character of man can be said to correlate with how people recognize and treat this vital force in living beings and things.

Benezet Bujo deals comprehensively with the idea of African morality and how it differs from Western morality or moral philosophy. Although his argumentation differs considerably from Mbiti's, he nevertheless emphasizes that African morality is not exclusively concerned with human persons or community which excludes a perspective of a monotheistic God. To substantiate his view, Bujo rejects the individualist idea which would suggest that the individual has obtained the ability to act responsibly merely by virtue of assenting to rational principles. In terms of Kant's idea, "the maximal realization of the rational will inevitably be reflected in the moral imperative" (cf. Edward, 1997: 45). Bujo would query this form of individualism as well as the rational as the foundation of the ethical imperative. The rational may be linked to the justification of morally correct behaviour, but it is not necessarily the basis of morality. African rationality is much more inclusive and deals with an embedded and even embodied sense of responsibility towards the community.

This notion cannot be regarded as illogical or irrational. In terms of the Western idea of logic, it may be pre-logical. As parody on the Cartesian cogito ergo sum, Bujo formulates: cognatus sum, ergo sumus ("I am related, therefore we are") in order to emphasize the difference in African anthropology and to highlight a morality that relates directly to communal embeddedness and societal bearing. This idea correlates with the widely known notion of Ubuntu: I am because we are. One becomes a human being only in a fellowship with the life of others. Udua refers to this as the African morality of community living or otherwise the morality in co-relationship. Bujo (2003) also resists the notion of Tempels' vital force, for the simple reason that it 
might have too many individualistic overtones and that vital force is a consequence and goal of moral conduct and not its basis. On the other hand, he is also aware of the imperative not to embrace a form of communitarianism as a principle for African morality. The dictum "I am related, therefore we are" protects the individual from being dominated by a group moral without being part of the construction of that moral.

The community itself is also understood as more than the visible community and includes the ancestors as well as those not yet born. This emphasizes the careful nature taken to constitute the moral foundations of a given community, for it is not a 'now' ideology rather it is a "generational one". One should also be careful not to emphasize communality as the absolute principle, for in Igbo, according to Achebe (1998:70) cosmology postulates the idea that "the individual is both a unique creation and the work of a unique creator an idea underscoring individualism". The idea is, however, not developed into a form of absolute individualism, for the will of the community is upheld and no single person will win judgment against the people. Bujo underscores the significance of the community, including the ancestors as the living dead, for an understanding of African morality. He warns, however, that the emphasis on the community should not lead to an ethno-centric ghetto morality which would condone all customary practices as good. He continues to show that the African community and its values should be considered in cases of ethical justification of actions and customs.

Adultery, for example, can only be judged in terms of the kind of marriage involved, and may wrongly be perceived as intrinsically abominable if an abstract concept of sexual morality is the point of departure. Adultery in a monogamous marriage clearly differs from what outsiders may hold regarding polygamous marriages. African morality does not subscribe to a natural law (ius naturale) in the sense that the observance of the natural laws of nature would indicate the moral path and what is regarded as a violation of the natural law. Even Aquinas postulated a divine origin of these laws which cannot be retrieved rationally in an absolute sense. This is not to say that African morality calls into question the possibility of universal moral codes, but these relate to the experiences and values of the community as well as to the historical narrative tradition in-forming the essence and values of the community. African morality also has a dialogical narrative dimension, reflected in story, myth, ritual, custom, and proverb.

This textualization concerns the transmission of not only the virtues, but also the vices which are to be avoided. It is surely not a recursive-reflexive justification of morality in the sense used by Habermas, whereby societal discourse at particular junctures defines the moral value or virtue. Community in the African context is the basis for morality in that it guarantees the well-being of both the individual and the community. The judgment as well as the justification of good and bad (evil) is not in terms of reason only, but this does not necessarily mean that it is irrational. The collective input of practice, custom, ritual, and accompanying narrative textualization makes the moral imperative and its justification nearly self-evident. Bujo (2003:202-203) would call this the "morality of memoria" within an all-embracing fellowship. The metaphysical assumption that the living dead are also an informing agency of morality does not render the justification irrational. Often in ritual and through the metaphoric meaning of the masks, the invisible is made present and the mighty deeds of the ancestor are narrated with a strong moral bearing on the audience. It is a rationality related to another worldview and to metaphysical presences that cannot be portrayed derogatively as irrational because it differs from the so-called Western worldview.

One appreciates the nuance of Bujo's reflection as well as his emphasis on the community and its memoria script for moral actions. The fact that he is a Christian theologian makes for the obvious assumption that the deity should be maintained as authority behind the moral imperative notwithstanding the emphasis on the community as foundation of morality; this confirms a duality in his position. This duality is also evident when he maintains that if morality is the Christian practice of faith, the grammar of moral performance of African peoples is also considered to be part of faith and religious expression. A legitimate reading of the African culture and its morality could therefore be a bridge for the incarnation of Christianity in Africa. Such a Christian reflection may be granted, but it may also be questioned in terms of a legitimate exploration of African morality 
without a Christianizing reference. It should and must be possible to describe African morality within its own context of performance, reflection and putting into language without the bias of the Christian episteme.

\section{Evaluation and Conclusion}

To portray more views would not advance the substance of the current discussion from which authentic empirical research was excluded. However, numerous important issues have surfaced. It has become evident that the concept of religion and faith, coined in Western, Christian traditions and transposed onto what is perceived to be African indigenous religion, mitigates against efforts from the continent itself to put into language the phenomena we call religion and morality. This impasse correlates directly to the difficulty of trying to define the conceptualization of morality in African thought. The inference from beyond the continent as well as from Christian-oriented thinkers on the continent has been too easily drawn: If African cosmology indicates a divinely-destined creation, that deity should also be the absolute norm for the moral imperative. This is why many scholars believe that in African thought, religion is the foundation of morality and that the moral imperative is derived from the deity; thus that faith gives sense to morality. This position has been challenged by many "Afrocentric" thinkers who stress the collective responsibility towards the community; including nature and the animal world. The collective responsibility is also informed by a rich collective memory and narrative textualisation, which ameliorate the justification of the moral imperative. This is not necessarily conducted in conscious rational terms but in a self-evident manner. In this sense, I am of the opinion that the moral imperative in African thought differs from what is usually understood by this concept in moral discourse. Apart from orthodox religious claims to ultimate values, moral discourse is mainly concerned with a kind of "justification" for an actual or proposed act of an individual, a group of persons or, indirectly, of an institution. Moral argument in a particular case is thus to find the "best" justification for some actual or proposed act. But this sense of moral justification does not apply to the African reality.

The conduct of the members of African indigenous communities is not judged by fellow members by means of reasoning. There is no moral reasoning for the purposes of moral justification Moral appraisals are rather made by reference to sets of values and standards prescribed by tradition, custom, practice, as well as social and family codes. These moral codes are not fixed in an absolute sense as universals, but may change with the transformation of society. Although the ancestors' presence and advice are part of the moral frame of reference, and guidance may ritually be sought, they are viewed as an extension of the community and not as part of the instruction of the deity. The fact is that morality in African thought does not necessarily involve a justification with reference to a deity. This is not to say that African cosmology is unaware of a creator deity. This deity is, however, not perceived as the custodian or guardian of the moral code. The sanction of the moral code relates to the intrinsic orientation towards the well-being of the community and its members. Through tradition, practice, custom, and memory, the community has arrived at these moral codes. The moral code is value-embedded. It is not a result of natural laws, but it is also not to be denied that natural observation may have influenced the moral code. One is therefore tempted to conclude that one can admit to an autonomous morality, if it is not erroneously understood to be intrinsically denying the existence of a deity.

It is quite notable that the construction of moral knowledge in African indigenous communities relates to their mode of understanding reality and within this reality, the well-being of the community is the central concern. If this preliminary inquiry has but one contribution to make, it is to stress the dire need for empirical evidence of how indigenous African people put their perceptions of what they consider moral codes and ethical conduct into language. This can only be done in conjunction with a critical interrogation of the Western religious episteme as frame of reference in descriptions of African thought and religion. The post-colonial reality provides a space to engage with the complexity of these phenomena in ways which allow the indigenous people to speak for themselves, but also to allow for the multi-valence and multi-layered dimensions of these concepts in 
African thought. For theological reflection and the practice of religious discourse on the continent, a departure from the homogenous assumptions based on a Western epistemology is paramount when seeking to gain conceptual clarity of concepts relating to indigenous religious expression as seen in Africa.

\section{References}

Bujo, B. (1990). African Christian Morality at the Age of Inculturation. Nairobi: St Paul Publications.

Dorjahn, V. (1997). "The Initiation and Training of the Temne Poro Members" in S. ottenberg, ed., African Religious Groups and Beliefs: Papers in Honor of William R. Bascom, Chanakya Puri, Sadar: Archana Publications.

Eliade, M. (1991). The Eliade Guide to World Relgions. San Francisco: HarperSanFrancisco.

Ferguson, J. “The Nature of Tribal Religion', in Adegbola, ed, Traditional Religion in West Africa, 242-243.

Guiterrez, G. (1984). We Drink from Our Own Wells: The Spiritual Journey of a People. New York: Orbis Book.

Ibekwe, E. (2013). Compatibility of Science and Religion. Owerri: Applause B.

Jahn, J. (1961). Muntu: An Outline of the New African Culture. Trans by M. Grene, New York: Grove Press.

Kung, H. (1991). Global Responsibility: In Search of a New World Ethic. New York: Crossroad.

Mbiti, J. (1970). Concepts of God in Africa. New York: Praeger Publishers

Mbiti, J. (1975). African Religious and Philosophy. London: Heinemann.

Metuh, I.(1981). God and Man in African Religion: A Case Study of the Igbo of Nigeria. London: Geoffrey Chapman.

Metuh, I. (1987). Comparative Studies of African Traditional Religions. Onitsha: IMICO Publishers.

Nicolas C. (1958). The Origins of Man Hawthorn Books, New York: US A.

Oliver J., ed. (1975). Religion and World History: A Selection from the Works of Christopher Dawson. New York: Doubleday and Co. Inc. Garden City,

Owen G. (1967). Man's Intervention in Nature. Hawthorn Books Inc., Scarborough Onatario : Canada,

Parrinder, G. (1969). Religion in Africa. Baltimore, Maryland: Penguine Books.

Sindima, H. (1990). "Community of Life: Ecological Theology in African Perspective", in C. Birch et al., eds., Liberating Life: Contemporary Approaches to Ecological Theology. Maryknoll, New York: Orbis Books, 144-146,

Wagner, G. (1949). The Bantu of Western Kenya: With Special Reference to the Vugusu and Logoli. Vol. I. London: Oxford University Press. 